\title{
Proposal of a Novel Criteria for Soil Corrosivity Evaluation and the Development of New Soil Synthetic Solutions for Laboratory Investigations
}

\author{
J. M. Giarola, ${ }^{a, c}$, B. A. F. Santos ${ }^{a}$, R. C. Souza ${ }^{a}$ (D, M. E. D. Serenario ${ }^{a}$, P. B. Martelli ${ }^{a}$, \\ E. A. Souza ${ }^{b}$ J. A. C. P. Gomes ${ }^{b}$ 마, A. H. S. Bueno ${ }^{a}$ \\ ${ }^{a}$ Universidade Federal de São João del-Rei (UFSJ), Praça Frei Orlando, 170, 36307-352, \\ São João del-Rei, MG, Brasil. \\ ${ }^{b}$ Universidade Federal do Rio de Janeiro (UFRJ), Centro de Tecnologia, Bloco F, Ilha do Fundão, \\ Rio de Janeiro, RJ, Brasil. \\ ${ }^{c}$ Universidade de São Paulo (USP), Escola de Engenharia de São Carlos, \\ Av. Trabalhador São Carlense 400, 13566-590, São Carlos, SP, Brasil.
}

Received: October 06, 2021; Revised: December 17, 2021; Accepted: December 21, 2021;

\begin{abstract}
A novel method to classify the aggressiveness of soil considering its physicochemical content and the development of new synthetic solutions for lab uses is proposed. The results showed that the main criteria existing in the literature for soil corrosivity classification might cause misunderstandings about the real aggressiveness. The synthetic solutions proposed aim to cover a wide range of soil found worldwide in order to refine the assessment of their characteristics hence their corrosivity. For the lab experiments, an API 5L X65 pipeline carbon steel was used. The solutions presented great reliability, and they seemed to be adequate to simulate soils with the presence of sulfate-reducing bacteria (SRB), chloride, and high $\mathrm{pH}$.
\end{abstract}

Keywords: Soil corrosion, physicochemical properties, synthetic soil solution, X65 steel.

\section{Introduction}

With the rapid growth of energy consumption, the demand for oil and natural gas all over the world has increased. Thereby, the use of high strength steel in pipeline construction is increasing rapidly. However, external corrosion can occur and reduce the safety and effectiveness of steels used in buried structures during their service period ${ }^{1-3}$. Many factors can lead to buried structures deterioration and, ultimately, to failure. External corrosion caused by the environment is one of the most damaging factors, and it can cause economic losses, loss of human lives, and environmental pollution.

Corrosion of buried steel structures has been extensively studied $^{4-10}$. In the field, soil corrosiveness is analyzed through different physicochemical parameters such as resistivity, redox potential, moisture, $\mathrm{pH}$, the presence of chloride, sulfate, sulfide, and sulfate-reducing bacteria (SRB) $)^{11-15}$. Several criteria for soil aggressiveness classification have been created based on the physicochemical parameters, and they have been presented in the literature ${ }^{16-20}$. Table 1 briefly shows the main criteria and the parameters that each one takes into account.

The influence of each parameter on soil corrosiveness is generally investigated isolated, and their combined effects are not fully understood. For instance, a recent study evaluated the resistivity effect on soil corrosiveness in which lower resistivities indicated higher corrosion tendency being sandy-clay and clayey-sand soils the ones with lower corrosive potential while clay materials present

*e-mail: josegiarola@gmail.com higher corrosivity index ${ }^{4}$. Other works sought to evaluate the moisture effects ${ }^{6,10,21,22}$. This parameter has a profound influence on soil corrosiveness, being important to highlight that the soils have a saturation limit for moisture ${ }^{6}$.

The impact of the presence of moisture can be understood as a season effect; that is, it varies throughout the year. Usually, the maximum corrosion rates are when moisture is around $60-70 \%$ of the saturation value ${ }^{6}$. Then, when increasing saturation, the corrosion rates decrease. This is due to the difficulty in $\mathrm{O}_{2}$ transport through the soil until the steel surface is hindered when the pores are filled with water ${ }^{6,23}$.

Another critical parameter is the soil $\mathrm{pH}$ once the corrosion mechanisms occur differently under acidic, neutral, or alkaline environments. In general, the soil $\mathrm{pH}$ is around $5-8^{11}$ but these values may change due to the presence of contaminants. Regarding buried structures such as pipelines, regions with higher $\mathrm{pH}$ (alkaline) contribute to forming a passive film that forms a barrier between the active steel surface and the medium, then increasing the corrosion resistance of the structures ${ }^{24-26}$. In addition to $\mathrm{pH}$, the presence of chloride ions $\left(\mathrm{Cl}^{-}\right)$has been widely studied, concluding that higher corrosion rates are expected when a high concentration of $\mathrm{Cl}^{-}$are observed ${ }^{2,25,27}$.

Lastly, but not less important, a crucial parameter for the correct determination of the soil aggressiveness is the presence or not of sulfate-reducing bacteria (SRB). It plays a decisive role because of the metabolic activity of these microorganisms that may lead to severe corrosion in the structures $^{28-30}$. 
To study soils in the laboratories, the NS4 synthetic soil solution is widely used aiming to evaluate corrosive soils $\mathrm{s}^{7,831,32}$. This standard solution was developed by Parkins ${ }^{33}$, considering the diversity of chemical composition that soils can have. However, the NS4 solution is not ideal for representing all soil types. Therefore, some authors conducted modifications in the NS4 solution to simulate the specific characteristics of certain soils. Wu et al. ${ }^{30}$ used the NS4 solution with the addition of bacterial cultures to study stress corrosion cracking (SCC) on the X80 steel under SRB environments. Bueno et al. ${ }^{8}$ used an NS4 solution contaminated with sodium thiosulfate $\left(\mathrm{Na}_{2} \mathrm{~S}_{2} \mathrm{O}_{3}\right)$ in which, by the reduction of the thiosulfate ion $\left(\mathrm{S}_{2} \mathrm{O}_{3}{ }^{2-}\right)$, they observed the formation of hydrogen sulfide $\left(\mathrm{H}_{2} \mathrm{~S}\right)$, a compound commonly produced during the anaerobic breathing of SRB.

For that reason, this work seeks to make a comparative analysis of the different evaluation methods for soil aggressiveness present in the literature. The criteria of Starkey and Wight ${ }^{16}$, Robison ${ }^{17}$, AWWA ${ }^{18}$, Steinrath ${ }^{19}$, and Steinrath modified ${ }^{20}$ were assessed. In addition, soil solutions derived were developed to comprehend better the tendencies observed with the soil analysis and also to provide complementing alternatives for the NS4 standard solution. Potentiodynamic polarization tests were used to infer soil aggressiveness through electrochemical parameters.

\section{Experimental Procedure}

The main objective of this study was to develop a new criterion for soil characterization and propose new synthetic solutions to be used in the laboratory. To achieve it, 6 steps were set, and they are shown in Figure 1.

In the first step, different soils were selected and collected to obtain a wide diversity of physicochemical properties to be analyzed.

The second step consisted in analyzing each soil aggressiveness through the main indexes found in the literature (Table 1), aiming to assess the divergencies between each one.

In the third step, the aqueous extract of each soil was analyzed by electrochemical tests, allowing a comparison between the electrochemical responses and the index classification.

The fourth step was dedicated to comprehending the effects of chloride concentration and different $\mathrm{pH}$ values on soil corrosivity.

Based on steps 2, 3, and 4, a new classification index for soil corrosiveness is proposed in the fifth step.

Finally, on the sixth step, new synthetic solutions for soils are proposed to be used in a laboratory simulating different environments.

\subsection{Material}

The samples of soils used in this work were collected in eight different points, being: 5 samples collection near buried pipelines in a deep approximately 3 meters at Rio de Janeiro, RJ, Brazil (soil 1 to soil 5) and 3 types of soil close to power transmission line towers at a depth of $50 \mathrm{~cm}$ at São João del Rei, MG, Brazil (solo 6 to soil 8). All the soils were collected with a maximum distance of 1 meter from each buried structure.

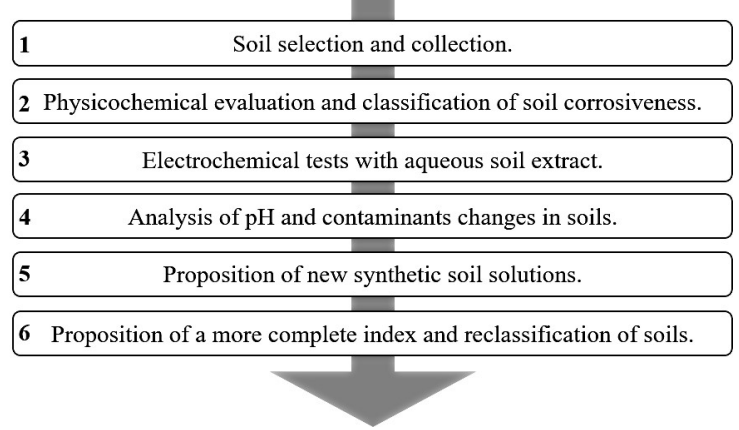

Figure 1. Flowchart of the work steps.

Table 1. Most common criteria for soil aggressiveness.

\begin{tabular}{cc}
\hline Criteria & Parameters \\
\hline Starkey and Wight $^{16}$ & Redox Potential \\
\hline Robison $^{17}$ & Resistivity \\
\hline AWWA $^{18}$ & $\begin{array}{c}\text { Resistivity, } \mathrm{pH} \text {, redox } \\
\text { potential, sulfate concentration } \\
\text { and, moisture }\end{array}$ \\
\hline Steinrath Indexes & Resistivity, $\mathrm{pH}$, redox \\
& $\begin{array}{c}\text { potential, chloride, sulfate } \\
\text { and sulfide concentration and, } \\
\text { moisture }\end{array}$ \\
\hline Modified Steinrath Indexes & $\begin{array}{c}20 \\
\text { pesistivity, pH, redox } \\
\text { pulfide concentration, moisture } \\
\text { and, sulfate-reducing bacteria }\end{array}$ \\
\hline
\end{tabular}

For the electrochemical measurements, the sample cross-section (Figure 2a) was machined from the API 5L X65 carbon steel and tested as received, without heat-treatment. The chemical composition in weight percentage is $0.09 \%$ wt. C, $0.27 \%$ wt. $\mathrm{Si}, 1.45 \%$ wt. Mn, $0.013 \%$ wt. P, $0.002 \%$ wt. S, $0.08 \%$ wt. Cr, $0.01 \%$ wt. $\mathrm{Ni}$, and $0.07 \%$ wt. Mo). The carbon steel presented a ferritic/pearlitic microstructure with homogeneous pearlite distribution, as seen in Figure $2 \mathrm{~b}$.

\subsection{Physicochemical characterization of the soil samples}

The physicochemical soil analyses were evaluated by Starkey and Wight criteria ${ }^{16}$, Robison's criteria ${ }^{17}$, AWWA (American Water Works Association) ${ }^{18}$, Steinrath ${ }^{19}$, and Modified Steinrath Indexes ${ }^{20}$.

The resistivity, redox, and electrochemical potentials were measured in situ, on the local where the soils were collected, were conducted 3 times each. The in situ resistivity measurement was carried out following the standard NBR $7117^{34}$ using the Werner method, in which 4 electrodes are equally positioned in a straight line with at $3 \mathrm{~m}$ distance and minimum penetrating depth equal to $5 \%$ of the electrodes distance. The soil resistivity was carried out using the Megabras MTD20kwe resistivity meter. For redox potential measurements based on BS 1377, Part $9^{35}$, platinum electrode was positioned at $100 \mathrm{~mm}$ distance from the saturated calomel electrode (SCE). After assembling 
this system, the positive terminal of the multimeter was connected to the platinum electrode and the negative terminal to the saturated calomel electrode. To guarantee the original conditions of soil oxygenation, the recorded value was the first shown on the equipment's display.

The analysis of moisture, $\mathrm{pH}$, chloride, sulfate, sulfide and sulfate reducing bacteria (SRB) of each soil was conducted in the laboratory. The $\mathrm{pH}$ was determined by the potentiometric method in soil suspension in distilled water using HANNA HI 2221 pHmeter. Sulfate and sulfide were determined by molecular absorption spectrophotometry and chloride content following the Mhor method ${ }^{20}$.

The SRB measurement was carried out through Postgate's methods ${ }^{36,37}$. The presence of SRB was not evaluated on soils 6,7 , and 8 due to the time between collecting and bringing them to the lab that was superior than $24 \mathrm{~h}$.

The moisture of the soil was analyzed according to the following procedure: a $500 \mathrm{~g}$ sample of each wet soil was dried at room temperature for $48 \mathrm{~h}$, and the residual moisture was measured. A sample of $10 \mathrm{~g}$ of soil was weighed and dried in an oven for two hours at $105^{\circ} \mathrm{C}$. After cooling in air, the sample was weighed. The procedure was repeated until a constant mass was reached. The soil moisture content was obtained by the difference between the initial and final mass.

\subsection{Electrochemical measurement}

The potentiodynamic polarization was used to investigate the electrochemical behavior of the synthetic solutions and aqueous extract of the soil in contact with API 5L X65 carbon steel. The measurements were conducted by an AUTOLAB type Multi Autolab Cabinet potentiostat using a traditional three-electrode system. The steel sample, mounted in epoxy resin with an exposure area of $1.00 \mathrm{~cm}^{2}$ was used as the working electrode, a saturated calomel electrode (SCE) as the reference electrode, and a platinum wire as the counter electrode.

The sample was ground up to 600-grit paper before the experiment and cleaned using alcohol and deionized water.
The open circuit potential (OCP) was measured for $30 \mathrm{~min}$ in order to obtain a stable potential. Subsequently, the potentiodynamic polarization tests started at $-1.2 \mathrm{~V}$ below OCP and ended when the system reached a potential $1.2 \mathrm{~V}$ above OCP. A scan rate of $30 \mathrm{mV} / \mathrm{s}$ was applied. For each condition tested, three polarization measures were taken in different samples. Since the curves were similar, only one condition was presented in this study.

The current density was obtained at $100 \mathrm{mV}$ above the OCP, and the corrosion potential (Ecorr) was considered the same at the OCP.

The aqueous extract of the soil was prepared according to the following procedure: the sample was ground and submitted to screening with sieves of $2.5 \mathrm{~mm}$. A solution of $200 \mathrm{~g}$ of dry soil and 1,000 $\mathrm{mL}$ of water were prepared in a beaker and agitated after each interval of 30 minutes for six hours using a glass stick. The beaker was covered with a polymeric film, and the mixture remained at rest for $48 \mathrm{~h}$. After soil decantation, the liquid phase (aqueous extract) was extracted and filtered before being ready to be used ${ }^{38}$.

Among the soils evaluated, soil 8 was the one with the lowest concentrations of chloride $\left(\mathrm{Cl}^{-}\right)$, sulfate $\left(\mathrm{SO}_{4}^{2-}\right)$, and sulfide $\left(\mathrm{S}^{2-}\right)$. Aiming to evaluate the influence of $\mathrm{pH}$ and the presence of chloride, three modified soils (MS1, MS2, and MS3) were developed from soil 8, as shown in Table 2. For $\mathrm{SM} 1,3.5 \%$ wt. $\mathrm{NaCl}$ was added to simulate seashore environments; for MS2, 5\% of cement was added in order to increase $\mathrm{pH}$ and simulate an alkaline soil; finally, for the MS3, it was added both $5 \%$ of cement and $3.5 \%$ wt. $\mathrm{NaCl}$ to evaluate the combined effects of $\mathrm{pH}$ and presence of $\mathrm{Cl}^{-}$.

The synthetic solutions proposed in this study were developed from the NS4 standard solution, which was

Table 2. Modified soils contente.

\begin{tabular}{cc}
\hline Modified soils & Content \\
\hline MS1 & Soil $8+3.5 \% \mathrm{NaCl}$ \\
\hline MS2 & Soil $8+5 \%$ cement \\
\hline MS3 & Soil $8+5 \%$ cement $+3.5 \% \mathrm{NaCl}$ \\
\hline
\end{tabular}
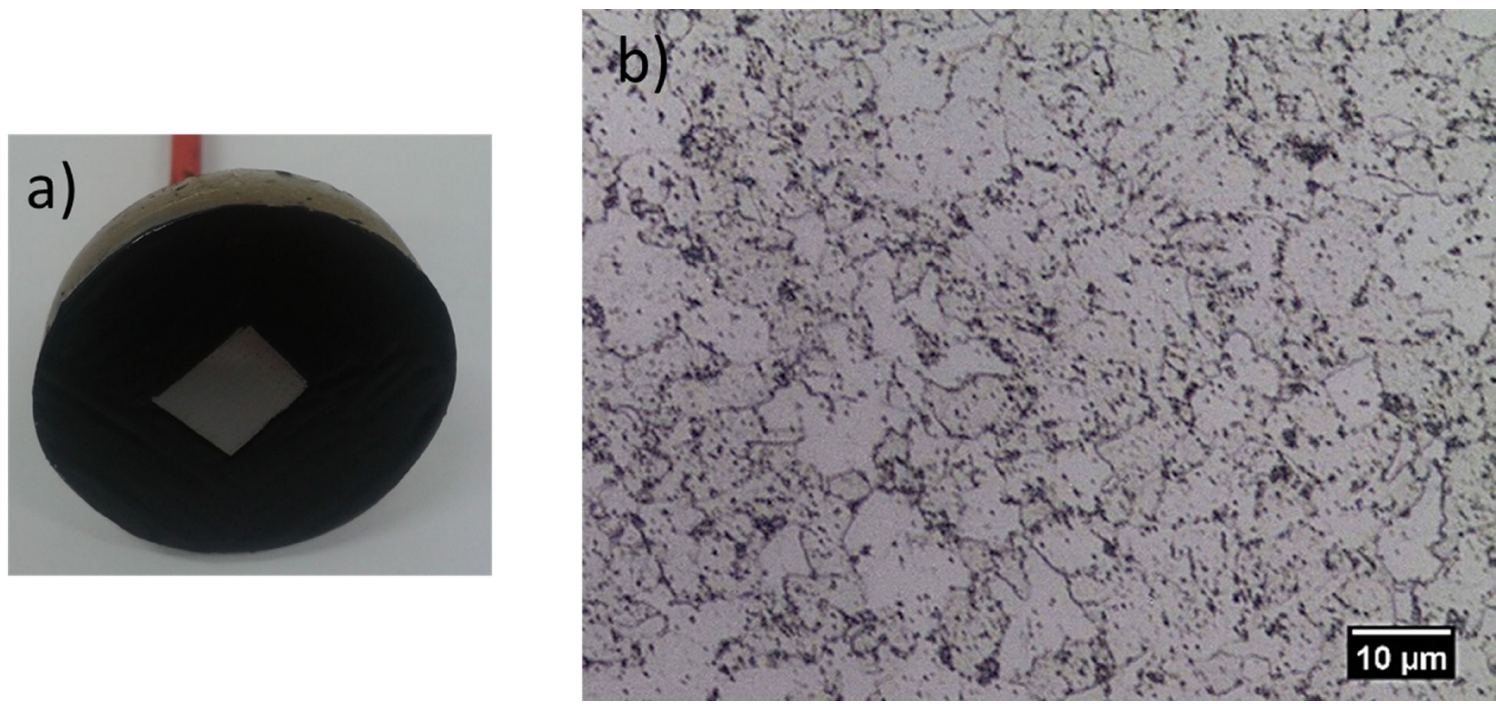

Figure 2. a) Sample cross-section for the electrochemical measurements and b) Microstructure of API 5L X65 carbon steel. 
prepared with analytical grade reagents and distilled water and deaerated with a gas mixture of $5 \% \mathrm{CO}_{2}+95 \% \mathrm{~N}_{2}$ (Table 3 ).

Solution 1 is the NS4 solution standard ${ }^{33}$. The synthetic solution SRB (SS-SRB) with the addition of sodium thiosulfate $\left(\mathrm{NaS}_{2} \mathrm{O}_{3} \cdot 5 \mathrm{H}_{2} \mathrm{O}\right)$ was performed to simulate soils contaminated with sulfate reducing bacteria (SRB). The thiosulfate simulates the effect of $\mathrm{H}_{2} \mathrm{~S}$ in synthetic soil solution, which can be compared to the effect of SRB in the same environment. The concentration $10^{-3} \mathrm{~mol} / \mathrm{L}(2.481 \mathrm{~g} / \mathrm{L})$ was used due to later results presented in the literature by Bueno et al. ${ }^{8}$. The synthetic solution Chloride (SS-Cl) was intended to study the seashore soils that present a high concentration of chloride ions. The concentration used of $3.5 \%$ wt. $\mathrm{NaCl}$ was selected based on the literature $27,39,40$. The cement was added in the synthetic solution alkaline (SS-ALK) to increase the $\mathrm{pH}$ in the range between 12 and 13 , featuring alkaline soil. In order to evaluate the influence of the bacteria in the alkaline solution, the SS-SRB-ALK solution was developed containing both SRB and cement. Finally, the synthetic Solution Chloride Alkaline (SS-Cl-AKL) represents the anti-corrosive solutions of seashore soils, with the presence of chloride ions and cement. To reach the ideal concentration of cement, electrochemical tests were performed with a carbon steel sample immersed in solutions with 5, 10, and $15 \%$ wt. cement. The results showed that there was no significant increase in alkalinity with the increase of cement, then the lowest mass (5\%) was used in all alkaline solutions.

\section{Results}

\subsection{Methods to evaluate soil corrosivity based on physicochemical analysis}

Figure 3 exhibits photos of a sample of each of the eight soils collected, in which it is possible to observe the change in coloring in relation to the place it was collected. Soils 1 to 5 were grayish, whereas soils 6 to 8 were reddish. Some authors ${ }^{41,42}$ reported that grayish and clayey soils with a characteristic $\mathrm{H}_{2} \mathrm{~S}$ odor are associated with the presence of SRB. This assumption will be confirmed in Table 4.

Table 4 shows the results of physicochemical parameters for each soil. It was not possible to carry out SRB measurement

Table 3. Chemical composition of NS4 solution and the synthetic soil solutions proposed in this work.

\begin{tabular}{|c|c|c|c|c|c|c|c|c|}
\hline \multirow[b]{2}{*}{ Solutions } & \multirow[b]{2}{*}{$\mathrm{pH}$} & \multicolumn{7}{|c|}{ Content } \\
\hline & & $\begin{array}{l}\mathrm{KCl} \\
(\mathrm{g} / \mathrm{L})\end{array}$ & $\begin{array}{l}\mathrm{CaCl}_{2} \\
(\mathrm{~g} / \mathrm{L})\end{array}$ & $\begin{array}{c}\mathrm{NaHCO}_{3} \\
(\mathrm{~g} / \mathrm{L})\end{array}$ & $\begin{array}{c}\mathrm{MgSO}_{4} .7 \mathrm{H}_{2} \mathrm{O} \\
(\mathrm{g} / \mathrm{L})\end{array}$ & $\begin{array}{c}\mathrm{NaS}_{2} \mathrm{O}_{3} .5 \mathrm{H}_{2} \mathrm{O} \\
(\mathrm{g} / \mathrm{L})\end{array}$ & $\begin{array}{c}\mathrm{NaCl} \\
\text { (wt. \%) }\end{array}$ & $\begin{array}{l}\text { Cement } \\
\text { (wt. \%) }\end{array}$ \\
\hline NS4 & 6.87 & 0.122 & 0.093 & 0.483 & 0.131 & 0 & 0 & 0 \\
\hline $\begin{array}{l}\text { Synthetic Solution } \\
\text { SRB (SS-SRB) }\end{array}$ & 6.40 & 0.122 & 0.093 & 0.483 & 0.131 & 2.481 & 0 & 0 \\
\hline $\begin{array}{l}\text { Synthetic Solution } \\
\text { Chloride (SS-Cl) }\end{array}$ & 6.87 & 0.122 & 0.093 & 0.483 & 0.131 & 0 & 3.5 & 0 \\
\hline $\begin{array}{c}\text { Synthetic Solution } \\
\text { Alkaline } \\
\text { (SS-ALK) }\end{array}$ & 12.8 & 0.122 & 0.093 & 0.483 & 0.131 & 0 & 0 & 5 \\
\hline $\begin{array}{l}\text { Synthetic Solution } \\
\text { SRB Alkaline } \\
\text { (SS-SRB-ALK) }\end{array}$ & 12.8 & 0.122 & 0.093 & 0.483 & 0.131 & 2.481 & 0 & 5 \\
\hline $\begin{array}{l}\text { Synthetic Solution } \\
\text { Chloride Alkaline } \\
\text { (SS-Cl-AKL) }\end{array}$ & 12.4 & 0.122 & 0.093 & 0.483 & 0.131 & 0 & 3.5 & 5 \\
\hline
\end{tabular}
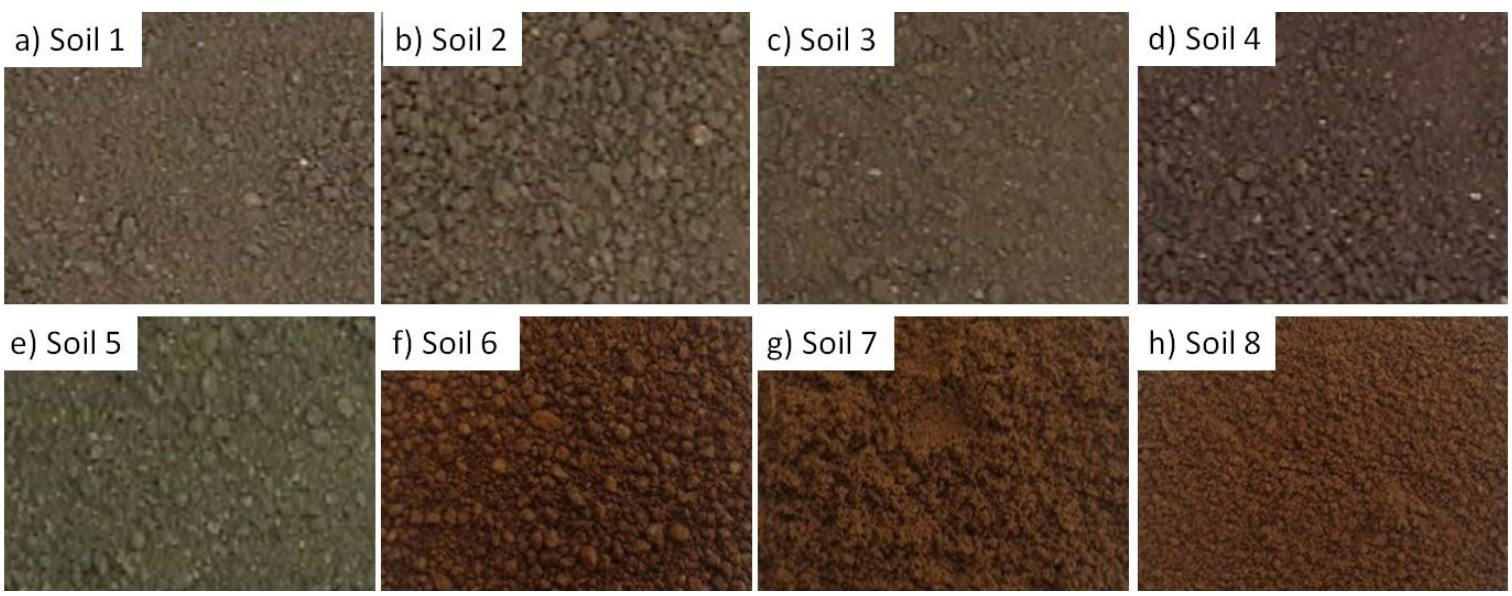

Figure 3. Photos of eight soil samples collected in different regions. Soil 1 to soil 5 collection in Rio de Janeiro and soil 6 to soil 8 collection in São João del Rei. 
in soils 6 to 8 , collected near to energy transmission tower, due to the time between collection soil and arrival process at the laboratory that was longer than $24 \mathrm{~h}$.

The critical analysis of soil corrosivity was carried out through its physicochemical and bacteriological parameters using different methods available in the literature and used in the field in order to compare their effectiveness. Figure 4 presents the classification of soils corrosivity by different methods. Starkey and Wight criteria (Figure 4a) analyzes soil corrosivity associated with redox potential ${ }^{16}$. Robison's criteria (Figure 4b) examines through resistivity ${ }^{17}$. In the AWWA method (Figure 4c), the scoring system works by assigning a point value to each of the following soil properties: soil resistivity, $\mathrm{pH}$, redox potential, sulfate concentration and moisture content ${ }^{18}$. The most complete method employed was Steinrath Indexes ${ }^{19}$, (Figure 4d) and Modified Steinrath Indexes ${ }^{20}$, (Figure 4e) that follows the same principle as AWWA but evaluates more parameters: soil resistivity, $\mathrm{pH}$, redox potential, chloride, sulfate, and sulfide concentration and, moisture content. In Steinrath modified indexes, the redox potential is exchanged for SRB since the redox potential implicitly assesses anaerobic microbiological activity.

Soil 1 presented high corrosivity for all criteria. What attributes this classification by Starkey and Wight ${ }^{16}$, Figure $4 a$, is the low value of redox potential (16.00 $\mathrm{mV} / \mathrm{SHE}$ ) (Table 4).

Table 4. Physical chemical and bacteriological parameters of soils.

\begin{tabular}{|c|c|c|c|c|c|c|c|c|}
\hline $\begin{array}{c}\text { Soil } \\
\text { Parameter }\end{array}$ & Soil 1 & Soil 2 & Soil 3 & Soil 4 & Soil 5 & Soil 6 & Soil 7 & Soil 8 \\
\hline $\begin{array}{c}\text { Resistivity } \\
(\Omega \mathrm{cm})\end{array}$ & 911.00 & $3,150.00$ & $70,000.00$ & 534.00 & 227.00 & $11,875.00$ & $1,103,862.00$ & $121,014.00$ \\
\hline $\begin{array}{c}\text { E Redox } \\
(\mathrm{mV} / \mathrm{ENH})\end{array}$ & 16.00 & 18.00 & 400.06 & 205.10 & 199.30 & 441.00 & 549.00 & 449.00 \\
\hline $\begin{array}{l}\text { Moisture } \\
(\%)\end{array}$ & 21.00 & 22.00 & 25.00 & 22.00 & 24.00 & 23.02 & 14.32 & 18.59 \\
\hline $\mathrm{pH}$ & 6.31 & 5.25 & 7.02 & 5.68 & 4.33 & 8.65 & 6.75 & 8.14 \\
\hline $\mathrm{Cl}^{-}(\mathrm{mg} / \mathrm{kg})$ & 97.80 & 224.70 & Absent & 100.00 & 200.00 & 4.30 & 3.18 & 1.57 \\
\hline $\begin{array}{c}\mathrm{SO}_{4}^{2-}(\mathrm{mg} / \\
\mathrm{kg})\end{array}$ & 29.30 & 20.00 & 25.00 & 90.00 & 120.00 & Absent & Absent & Absent \\
\hline $\mathrm{S}^{2-}(\mathrm{mg} / \mathrm{kg})$ & 2.90 & 0.30 & 8.60 & 0.25 & 1.67 & Absent & Absent & Absent \\
\hline $\begin{array}{c}\text { BRS } \\
(\mathrm{NMP} / \mathrm{g})\end{array}$ & $1.40 \mathrm{E} 4$ & 15.80 & Absent & 8.70 & $8.60 \mathrm{E} 4$ & - & - & - \\
\hline Color soil & Clayey gray & Clayey gray & Light brown & Reddish & $\begin{array}{l}\text { Grayish/ } \\
\text { swamp }\end{array}$ & Brown & Brown & Brown \\
\hline
\end{tabular}
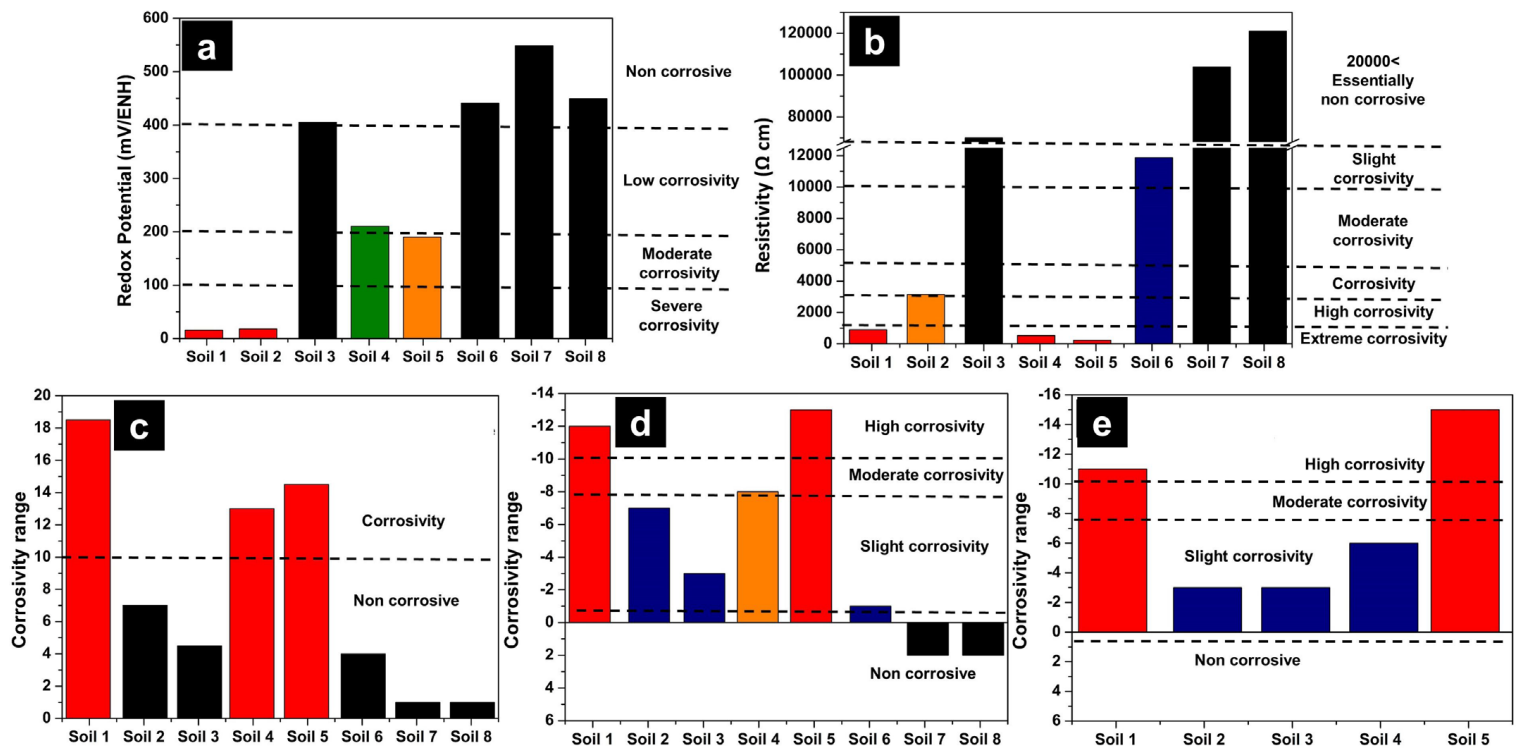

Figure 4. Corrosivity classification of soils in accordance with its physical-chemical and bacteriological parameters by: a) Starkey and Wight criteria ${ }^{16}$, b) Robison's criteria ${ }^{17}$, c) AWWA method ${ }^{18}$, d) Steinrath ${ }^{19}$ and e) Modified Steinrath Indexes ${ }^{20}$. The dashed lines indicate the minimal and maximum levels of aggressiveness. 
By Robison's criteria ${ }^{17}$, the low resistivity $(911.00 \Omega \mathrm{cm})$ classified this soil as "extremely corrosive" (Figure 4b). For AWWA criteria, the soil is only "corrosive", Figure 4c while for Steinrath index ${ }^{19}$, it is "highly corrosive", Figure 4d. For both AWWA and Steinrath criteria, the low resistivity and redox potential, as well as the high concentration of sulfide $(2.90 \mathrm{mg} / \mathrm{kg})$, had a considerable influence, even though for AWWA only the resistivity attributes almost all points to reach the score to the "corrosive" classification. By the Steinrath modified index ${ }^{20}$, soil 1 is also "highly corrosive" (Figure 4e) due to the same reasons found for the Steinrath method (Figure 4d) and also by the presence of SRB (1.40 NMP/g).

Soil 2, on the other hand, presented a wide range of classification through all criteria used. For Starkey and Wight (Figure 4a), soil 2 was classified as "severe corrosivity" due to the low value of redox potential (18.00 mV/SHE) (Table 4). For Robison's criteria, given the value of resistivity $(3,150.00 \Omega \mathrm{cm})$, it is classified as "corrosive" (Figure 4b and Table 4). However, surprisingly for AWWA, soil 2 was considered as "non-corrosive" (Figure 4c). Although this criterion considers various parameters, the ones that scored were the low redox potential and the moisture, which were not sufficient to reach the minimum score of the "corrosive" region. For the Steinrath index (Figure 4d), soil 2 was classified as "slight corrosivity" given the low redox potential, the median values for resistivity and the presence of sulfide $(0.30 \mathrm{mg} /$ $\mathrm{kg})$, and chloride $(224.70 \mathrm{mg} / \mathrm{kg})$. The latter was the highest concentration observed for all soils. The Steinrath modified index soil 2 was also considered with "slight corrosivity". Despite the low redox potential, which indicates anaerobic conditions, low amount of SRB was found (15.80 NMP/g) (Table 4), then only resistivity, sulfide, and chloride affected the aggressiveness of this soil.

Soil 3 was classified as "none corrosivity" by Starkey and Wight (Figure 4a) because of its redox potential superior to $400.00 \mathrm{mV} / \mathrm{SHE}$ (Table 4); as "slight corrosivity" by Robison's criteria (Figure 4b), given its resistivity being superior to $10.000 \Omega \mathrm{cm}$; "non-corrosive" through AWWA (Figure 4c), in which only moisture and sulfide scored; and "slight corrosivity" by both Starkey indexes, being the median values of resistivity $(70.000 \Omega \mathrm{cm})$ and the high concentration of sulfides $(8.60 \mathrm{mg} / \mathrm{kg})$ the only parameters that affected its corrosivity.

Soil 4 was classified as "low corrosivity" by Starkey and Wight because of the median values of redox potential $205.10 \mathrm{mV} / \mathrm{SHE}$ (Table 4). On the other hand, for Robison's criteria, it was classified as "high corrosivity" (Figure 4b) due to its low resistivity $(534.00 \Omega \mathrm{cm})$. From AWWA (Figure 4c), this soil is "corrosive" by the same reasons as for Robison's criteria. Considering both Steinrath Indexes (Figure $4 \mathrm{~d}$ and $4 \mathrm{e}$ ), the soil was classified as "moderate corrosivity", being the determining parameters the low resistivity, the presence of chloride $(100 \mathrm{mg} / \mathrm{kg})$, and sulfide $(0.25 \mathrm{mg} / \mathrm{kg})$. Although soil 4 has reducing characteristics and low redox potential, it has not presented $\mathrm{H}_{2} \mathrm{~S}$ odor during its collection, which was confirmed by the low presence of SRB (Table 4).

Soil 5 was considered of "high corrosivity" for all criteria used. By Starkey and Wight (Figure 4a) the low redox potential (199.30 mV/SHE) was decisive. For Robison's criteria (Figure 4b), it was due to the low resistivity $(227.00 \Omega \mathrm{cm})$, whereas for AWWA, besides resistivity, the high sulfide concentration $(1.67 \mathrm{mg} / \mathrm{kg})$ also influenced. Considering both Steinrath indexes (Figure 4d and 4e), soil 5 was the most aggressive among all soils evaluated. Apart from all parameters mentioned above, for the modified index (Figure 4e), the highest concentration of SRB observed (8.60E4 NMP/g) stood out.

Soil 6 was classified with "none corrosivity" by Starkey and Wight (Figure 4a), presenting high values of redox potential (441.00 mV/SHE); as "moderate corrosivity" by Robison's criteria (Figure 4b) because of the median resistivity $(1180 \Omega \mathrm{cm})$; again as "non-corrosive" by AWWA (Figure 4c), in which only resistivity scored, however, it did not provide the corrosive character to the soil. For the Steinrath indexes (Figure $4 \mathrm{~d}$ and $4 \mathrm{e}$ ), resistivity was the main parameter that led the soil to be classified with "moderate corrosivity".

Differently from the others, soils 7 and 8 were considered "non-corrosive" by all criteria analyzed. The soils did not show any corrosive parameter since they presented high resistivity $(1.10 \mathrm{E} 6$ and $1.21 \mathrm{E} 4 \Omega \mathrm{cm})$, high redox potential (549.00 and $449.00 \mathrm{mV} / \mathrm{SHE}$ ), and absence of chloride, sulfide, and sulfate (Table 4).

It is important to restate that soils 6,7 , and 8 were not evaluated through the Steinrath modified index due to the absence of data concerning the presence of SRB caused by the time spent between the collection and the tests, as explained in section 2.2 of this work. Even so, the soils showed redox potential above $400 \mathrm{mV}$, not presenting anaerobic characteristics. Also, during the collection, no $\mathrm{H}_{2} \mathrm{~S}$ odor was observed nor any grayish color (Figure 3), which are very common in soils with the presence of SRB, as reported by Bueno et al. ${ }^{41}$ and Tiller and $\mathrm{Corr}^{42}$.

\subsection{Electrochemical evaluation using aqueous soil extracts as corrosive media}

The aqueous extract, containing the soluble constituents of the soil, has been considered representative of some important characteristics of soil corrosivity. In this way, electrochemical polarization tests were carried out with an API X65 carbon steel sample to better understand the corrosion process in the studied soils. Besides, it allows the comparison between the corrosiveness of the soils obtained by the indices of physicochemical parameters. These tests were performed in aqueous extracts prepared from the evaluated soils.

It is important to highlight that these electrochemical tests do not account for the soil resistivity, redox potential, and moisture since they were evaluated using aqueous extracts. Also, the presence of SRB was not evaluated once the tests were conducted after $24 \mathrm{~h}$ of collecting the soils, according to the item in section 2.2 .

The soils generally showed similar electrochemical behavior, featuring a typical anodic dissolution without any passivation phenomenon. Due to these similarities, Figure 5 only presents the polarization curve of Soil 8 in order to ease viewing. The electrochemical data of all soils are shown in Table 5. 
Table 5 presents the parameters obtained from the analysis of each polarization curve. The higher current densities and lower corrosion potential (Ecorr) indicate less corrosion resistance.

All Ecorr are more positive than the $\mathrm{Fe} / \mathrm{Fe}^{2+}$ equilibrium potential, $-0.892 \mathrm{~V}_{\mathrm{SCE}}$ and except for soils $1\left(-0.646 \mathrm{~V}_{\mathrm{SCE}}\right)$ and $2\left(-0.585 \mathrm{~V}_{\mathrm{SCE}}\right)$ that are more negative than the $\mathrm{H} / \mathrm{H}^{+}$ equilibrium line; that is, they are in the region where the reduction of hydrogen occurs, and hydrogen embrittlement may occur, according to Pourbaix diagram for $\mathrm{Fe} / \mathrm{H}_{2} \mathrm{O}^{43}$. These lines depend on the $\mathrm{pH}$ of the environment, then the undergoing active dissolution due to being within the corrosion domain and the hydrogen reduction is occurring on the metal surface, except for soils 1 and 2, in which the hydrogen reduction is not likely to occur. The current densities verified in the naturally aerated cathodic curves can be attributed to the oxygen and hydrogen reduction reactions.

From Table 5, it is possible to observe that soils 1, 2, and 4 presented intermediate values of current density compared to the other soils, indicating moderate corrosion resistance. Soil 5 , in its turn, was the most corrosive, exhibiting the higher current density. Soils 6, 7, and 8, as well as soil 3, were the less corrosive ones, showing the lowest current density.

Although soil 2 presented more chloride than soil 5, it has one sixth of sulfate concentration (Table 4), ending up being less aggressive than soil 5 . The low chloride concentration is possibly the reason soils $3,6,7$, and 8 have been less corrosive through electrochemical evaluations.

Table 5. Electrochemical parameters determined in aqueous extract of soil.

\begin{tabular}{cccc}
\hline Soil & $\mathrm{pH}$ & Ecorr $\left(\mathrm{V}_{\mathrm{SCE}}\right)$ & $\begin{array}{c}\mathrm{i}\left(\mathrm{A} / \mathrm{cm}^{2}\right) \\
(100 \mathrm{mv} \text { above OCP })\end{array}$ \\
\hline 1 & 6.31 & -0.646 & $6.39 \mathrm{E}-5$ \\
\hline 2 & 5.25 & -0.585 & $7.02 \mathrm{E}-5$ \\
\hline 3 & 7.02 & -0.445 & $8.05 \mathrm{E}-6$ \\
\hline 4 & 5.68 & -0.446 & $1.83 \mathrm{E}-5$ \\
\hline 5 & 4.33 & -0.560 & $1.40 \mathrm{E}-4$ \\
\hline 6 & 8.65 & -0.775 & $7.85 \mathrm{E}-6$ \\
\hline 7 & 6.75 & -0.735 & $7.59 \mathrm{E}-6$ \\
\hline 8 & 8.14 & -0.743 & $6.58 \mathrm{E}-6$ \\
\hline
\end{tabular}

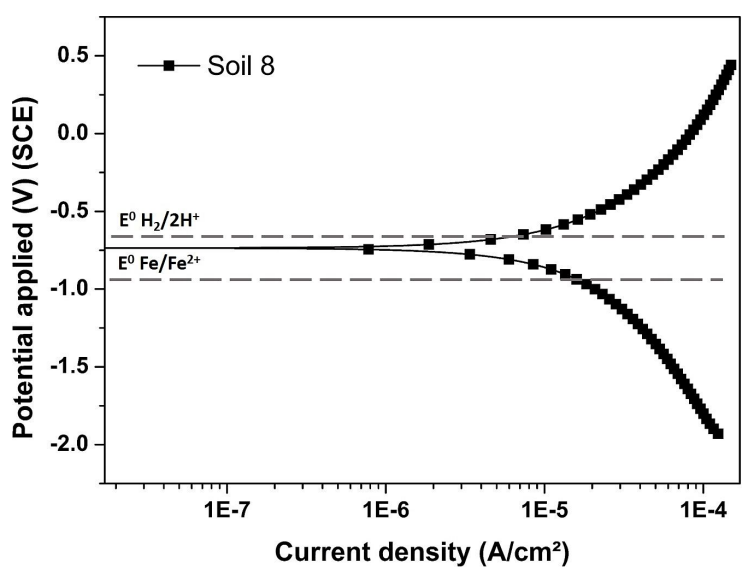

Figure 5. Polarization curve of API X65 steel in aqueous extract of Soil 8.

\subsection{Electrochemical evaluation using modified soils as corrosive media}

Figure 6 presents the polarization curves of the aqueous extract of soil 8 and its modified derivations MS1, MS2, and MS3, accordingly Table 6 . These electrochemical tests were performed with modified soil 8 in order to comprehend the influence of the addition of chloride and the $\mathrm{pH}$ effect on the soils corrosion resistance.

From Figure 6, it is possible to notice that the curves presented distinct electrochemical behavior. Soil 8 and MS1 presented an increase in the current density as the potential was applied, both exhibiting anodic dissolution. It is also possible to observe that the increase in the chloride led to an increase in the current density when comparing soil $8(0 \%$ wt. $\mathrm{NaCl})$ and $\mathrm{MS} 1(3.5 \%$ wt. $\mathrm{NaCl})$.

On the other hand, when $5 \%$ wt. of cement was added (MS2 and MS3), it promoted an increase in the medium $\mathrm{pH}$, creating an alkaline environment allowing the passivation phenomenon to be observed for the curves of both conditions. Also, it is possible to verify that soil samples with the addition of cement presented Ecorr more negative than the ones without cement (soil 8 and MS1). However, even though both MS2 and MS3 presented passivation, the one without the addition of $\mathrm{NaCl}, \mathrm{MS} 2$, exhibited greater passive domain before the pitting occurrence than its equivalent with chloride MS3, then featuring higher corrosion resistance.

Table 6 presents the parameters obtained from the analyses of each polarization result.

The Ecorr of soil 8 and MS1 are above the $\mathrm{Fe} / \mathrm{Fe}^{2+}$ equilibrium potential, $-0.892 \mathrm{~V}_{\mathrm{SEC}}$, according to the Pourbaix diagram $^{43}$, indicating active dissolution. The Ecorr of soils with alkaline $\mathrm{pH}$ that is, those with cement addition, are within the passivation domain of iron oxide $\left(\mathrm{Fe}_{3} \mathrm{O}_{4}\right)$, according to the Pourbaix diagram ${ }^{43}$. Therefore, the addition of cement creates conditions to form a stable layer of iron oxide on the metal surface. In other words, the soils with the addition of cement exhibited passive behavior.

In the MS3, as can be observed, $\mathrm{E}_{\text {pit }}$ decreases with increasing $\mathrm{Cl}^{-}$content, indicating an increase in pitting susceptibility caused by the addition of $\mathrm{Cl}^{-}$ions.

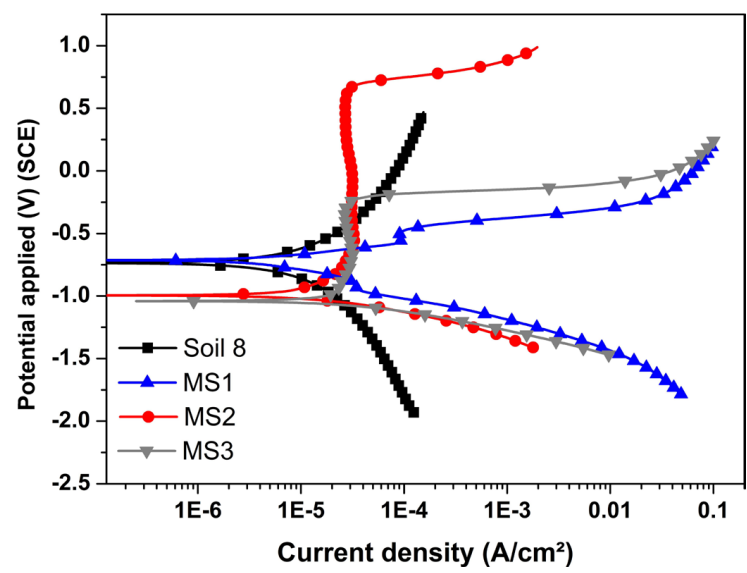

Figure 6. Polarization curves for soil 8 and its derivations with $3.5 \%$ (wt.) $\mathrm{NaCl}$ (MS1), with 5\% (wt.) cement (MS2) and with $3.5 \%$ (wt.) $\mathrm{NaCl}+5 \%$ (wt.) cement (MS3). 
Table 6. Electrochemical parameters determined in aqueous extract of soil 8 with cement and chloride.

\begin{tabular}{|c|c|c|c|c|c|}
\hline Soil & $\mathrm{pH}$ & Ecorr $\left(\mathrm{V}_{\mathrm{SCE}}\right)$ & $\begin{array}{c}\mathrm{i}\left(\mathrm{A} / \mathrm{cm}^{2}\right) \\
(100 \mathrm{mV} \text { above OCP })\end{array}$ & Epit $\left(\mathrm{V}_{\mathrm{SCE}}\right)$ & $\begin{array}{l}\text { Passivation Domain } \\
\text { (Epit- Ecorr) }\left(\mathrm{V}_{\mathrm{SCE}}\right)\end{array}$ \\
\hline Soil 8 & 8.14 & -0.743 & $6.58 \mathrm{E}-6$ & - & - \\
\hline MS1 & 7.13 & -0.709 & $4.19 \mathrm{E}-5$ & - & - \\
\hline MS2 & 12.73 & -0.994 & $1.54 \mathrm{E}-5$ & 0.674 & 1.668 \\
\hline MS3 & 13.29 & -1.044 & $2.31 \mathrm{E}-5$ & -0.251 & 0.793 \\
\hline
\end{tabular}

\subsection{Synthetics soil solutions}

From the NS4 solution, other synthetic solutions for laboratory use were studied and proposed, and they are presented in Table 3 , covering a wide variety of soil with different characteristics.

Polarization curves obtained from all solutions (Table 3) are presented in Figure 7, using an API 5L X65 steel sample in deaerated conditions. The corrosion potential and current density at $100 \mathrm{mV}$ above OCP were obtained from Figure 7, and they are shown in Table 7.

The addition of cement promoted an increase in corrosion potential. The Ecorr was shifted from around $-700 \mathrm{mV}$ in solutions NS4, SS-Cl, and SS-SBR to $-400 \mathrm{mV}$ in alkalized solutions SS-ALK, SS-Cl-ALK, and SS-SBR-ALK. There is also a clear indication that the cement causes a reduction in the anodic process. The reduction in current density when compared to the NS4 solution confirms this effect of cement. The main reason for these phenomena is that the cement increases the $\mathrm{pH}$ values. According to Pourbaix diagram ${ }^{43}$, iron oxide and hydroxide may form some protective compounds against corrosion in alkaline $\mathrm{pH}$, as the $\mathrm{Fe}_{3} \mathrm{O}_{4}$. In Figure 7 the curves with cement did not passivate however, the current densities decreased in relation to the same curves without the presence of cement, indicating that these solutions are less aggressive for steel. However, the Icorr increases faster in the solution SS-Cl-ALK, which means that the susceptibility of steel to corrosion increases.

Analyzing the current density, the solution that showed the highest anodic dissolution was SS-Cl (Table 7). This anodic dissolution behavior under active control was observed for all solutions except for the SS-SRB solution, which exhibits a surface with pseudo-passivation in thiosulphate solution.

The chloride ions interact more aggressively with the steel surfaces, causing a higher dissolution. Analyzing the current density data in Table 7 it is possible to affirm that the SS-SBR is less aggressive than SS-Cl and NS4.

\section{Discussion}

\subsection{Critical analyses of methods to evaluate soil corrosivity based on physicochemical analysis}

The soil corrosivity criteria consider different physicochemical parameters. Among them, resistivity presented the higher influence on the corrosivity results for all indexes. Soil resistivity is a measure of how much the soil resists or conducts electric current in which lower resistivity values mean higher corrosion rates ${ }^{11,25}$. Some authors ${ }^{13,14}$ reported that resistivity is the main soil property
Table 7. Electrochemical parameters determined in synthetic solutions.

\begin{tabular}{ccc}
\hline Solution & Ecorr $\left(\mathrm{V}_{\mathrm{SEC}}\right)$ & $\begin{array}{c}\mathrm{i}\left(\mathrm{A} / \mathrm{cm}^{2}\right) \\
(100 \mathrm{mv} \text { above OCP })\end{array}$ \\
\hline NS4 & -0.763 & $1.83 \mathrm{E}-04$ \\
\hline SS-Cl & -0.716 & $1.93 \mathrm{E}-3$ \\
\hline SS-SBR & -0.773 & $4.46 \mathrm{E}-6$ \\
\hline SS-ALK & -0.431 & $5.41 \mathrm{E}-7$ \\
\hline SS-Cl-ALK & -0.419 & $2.60 \mathrm{E}-7$ \\
\hline SS-SBR-ALK & -0.427 & $2.12 \mathrm{E}-7$ \\
\hline
\end{tabular}

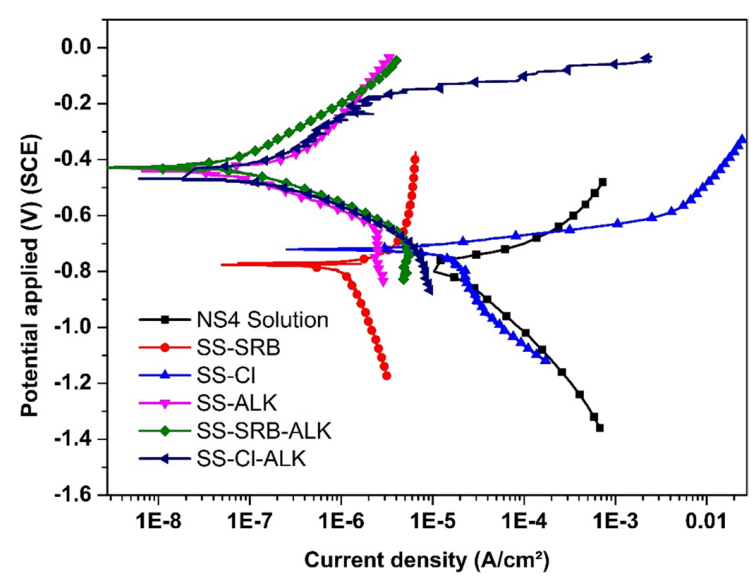

Figure 7. Polarization curves of API X65 steel in synthetic solutions.

related to pitting corrosion. The results presented by Ponciano and Bueno ${ }^{44}$ showed that significant changes in resistivity may appear in small distances for the same soil. This is risky since resistivity is the main parameter considered in some projects for cathodic protection, and a misinterpretation of this parameter when considering the soils may cause failures and even losses.

Another parameter that contributed for the high aggressiveness shown by soils was the redox potential. This indicates the aeration level of the soils in which low values mean better conditions for anaerobic microbiological activity $^{11,45}$. Furthermore, redox potential is also an important factor since it quantifies the soil capacity for electrons donation. Then, it is extremely related to the deterioration rate of metals ${ }^{46}$.

Regarding the $\mathrm{pH}$ effect, there is a divergence among the works in the literature. In general, the acidic environment with $\mathrm{pH}$ below 6 , is considered more corrosive than the neutral, $\mathrm{pH}$ between 6 and 8 , or the alkaline, with $\mathrm{pH}$ above $8^{47}$. According to Ismail and El-Shamy ${ }^{11}$, the $\mathrm{pH}$ range between 
5 and 8 , the range in which the soils were found, is not considered a dominant variable for corrosion rates. However, according to Ganiyu et al. ${ }^{45}$, soils with $\mathrm{pH}$ between 5.5 and 6.5 present a moderate corrosivity condition, $\mathrm{pH}$ between 6.5 and 7.5 are considered neutral corrosion and $\mathrm{pH}$ greater than 7.5 a slight corrosivity. Considering the soils evaluated in this work, the non-corrosive behavior was predominant, in agreement with the results of Ismail and El-Shamy ${ }^{11}$.

The water present in the soil allows forming the electrolyte necessary for the electrochemical reactions to occur $^{11}$. Therefore, moisture became a very important factor to be considered for soil corrosivity analyzes. The corrosion rates rise as the moisture is increased until a critical limit, and then it starts to decrease $\mathrm{e}^{6,22}$. This critical saturation limit occurs because as the porosities of the soil are filled with the electrolyte, the oxygen transport is limited, reducing the corrosion reactions ${ }^{6,23}$.

The chloride and sulfate ions generally increase soil corrosivity since they act directly in the anodic dissolution reactions of metals and decrease the electrical resistivity of the soil. The sulfate ions may be converted into sulfide by sulfate-reducing bacteria, then the presence of this ion might indicate anaerobic activity in the soil. This upholds the results found for soils 3, 6, 7 and 8, once they presented insignificant concentrations of sulfide and chloride. The less aggressiveness of these soils was also confirmed by the electrochemical tests (Table 5), where lower current densities were observed.

The effects caused by the presence of the SRB are not considered by most of the methods to evaluate the corrosivity. This may cause an erroneous analysis since the bacteria may catalyze the corrosive process reducing the corrosion resistance as well as increasing the steel susceptibility to stress corrosion cracking (SCC). During the SRB anaerobic breathing, the sulfate ions act as the reducing agent for the metabolization of organic matter, the same as the oxygen for aerobic breathing. The sulfide produced by the sulfate reduction is normally expelled in the form of hydrogen sulfide $\left(\mathrm{H}_{2} \mathrm{~S}\right)^{28,48}$. This gas is extremely toxic, and it is responsible for increasing the medium aggressiveness acting as an extra source of $\mathrm{H}^{+}$, which in turn reduces $\mathrm{pH}$. Furthermore, the $\mathrm{H}_{2} \mathrm{~S}$ corrosion mechanism, called sour corrosion, is known to form corrosion products when in contact with ferrous ions that, in favorable conditions, may cover the steel and contribute to the diminishing of corrosive processes ${ }^{30,49,50}$.

The soil aggressiveness analysis, Figure 4 and Table 4, makes it possible to observe that there are several physicochemical parameters influencing soil corrosivity; hence an isolated analysis of each might cause misinterpretations of its real aggressiveness. Soil 1 was one of the few that received the same classification (high corrosivity) for all criteria. This is due to its characteristics, such as low resistivity, low redox potential, and high concentration of sulfide and SRB. The same did not happen for soil 2, presenting divergences among the criteria used.

In general, soil 2 showed some aggressiveness; however, it did not show any by AWWA, which accounts mainly for the resistivity in which scores only with values lower than $2000 \Omega \mathrm{cm}$. For both Steinrath indexes, resistivity values lower than $12000 \Omega \mathrm{cm}$ are considered influencing soil corrosivity, the same as for Robison's criteria, in which values below $20000 \Omega \mathrm{cm}$ are considered slightly corrosive. In addition to this variation about the resistivity requirements accounted by AWWA, this criterion does not consider the presence of chloride ions in its classification system. Thus, although soil 2 has presented the greater amount of chloride among the soils evaluated, by AWWA, it is considered "noncorrosive". Doyle et al. ${ }^{14}$ reported that the AWWA system might be erroneous when identifying the soil corrosivity once that in their work, only $38 \%$ of the soils considered as "non-corrosive" were correct.

Soil 3, in its turn, the divergences occurred mainly because Starkey and Wight and Robison's criteria do not consider aggressive ions. The presence of sulfide led the soil to be classified as "slight corrosivity" by Steinrath and Steinrath modified. On the other hand, although the AWWA system considers sulfide, soil 3 was classified as "non-corrosive". The simplistic classification by the AWWA system in "corrosive" and "non-corrosive" has shown to be the main factor for misinterpretations.

Soil 4 presented a very low resistivity, and it was classified as "extreme corrosivity" by Robison's and as "corrosive" by AWWA. However, the median values of redox potential led it to be classified as "low corrosivity" by Starkey and Wight.

Soil 5, the same as for soil 1, was classified homogeneously for all criteria since it has all the characteristics of corrosive soil. Soils 6, 7, and 8 were the opposite of soil 5, presenting all criteria of a "non-corrosive" soil being classified as nonaggressive by all indexes considered.

Given the divergences in the classification of soil corrosivity from different criteria, it is possible to notice the complexity of evaluating the corrosive processes in buried structures. Then, idealistically, a great method to assess the soil corrosivity must consider as many physicochemical parameters as possible ${ }^{15,46}$, once that a simplistic classification might promote misunderstandings about the real corrosive processes $^{51}$.

Among all criteria used in this work, Steinrath indexes are the ones that consider most parameters. Even so, these indexes are still not ideal. An example is a fact that none soil the concentration of sulfate was considered relevant but, as shown in Table 5, soil 5 was the most corrosive one due to the combined presence of chloride and sulfate, turning it into a significant parameter through the electrochemical analyses. Regarding resistivity and $\mathrm{pH}$, the corrosive ranges considered by Steinrath are more restricted when compared with Robison's criteria and AWWA. Other authors ${ }^{45}$ also showed that the $\mathrm{pH}$ range that affects corrosivity differs from that considered by Steinrath ${ }^{19}$.

Considering all these factors, this study suggests an adaptation from the Steinrath index, aiming to comprise all the advantages of each criterion studied as well as each physicochemical parameter not considered by them.

Table 8 presents the proposed new index to evaluate the soil corrosivity, in which resistivity becomes to be considered in the same range of Robison's criteria, the redox potential is evaluated according to the less conservative Starkey and Wight criterion, and the $\mathrm{pH}$ in its turn is classified from the combination of AWWA method and the results found by Ganiyu et al. ${ }^{45}$. The classification by moisture, presence 
Table 8. Soil aggressiveness partial indexes.

\begin{tabular}{|c|c|c|}
\hline Parameter & Range & Partial index \\
\hline \multirow{6}{*}{ Resistivity $(\Omega . \mathrm{cm})$} & $>20000$ & +1 \\
\hline & $20000-10000$ & 0 \\
\hline & $10000-5000$ & -1 \\
\hline & $5000-3000$ & -2 \\
\hline & $3000-1000$ & -3 \\
\hline & $<1000$ & -4 \\
\hline \multirow{4}{*}{ E Redox (mV/SHE) } & $>400$ & +2 \\
\hline & $400-200$ & 0 \\
\hline & $200-100$ & -2 \\
\hline & $<100$ & -4 \\
\hline \multirow{5}{*}{$\mathrm{pH}$} & $>7.5$ & -1 \\
\hline & $6.5-7.5$ & 0 \\
\hline & $6.5-5.5$ & -2 \\
\hline & $2-5.5$ & -3 \\
\hline & $<2$ & -4 \\
\hline \multirow{2}{*}{ Moisture (\%) } & $<20$ & 0 \\
\hline & $>20$ & -1 \\
\hline \multirow{3}{*}{$\mathrm{Cl}^{-}(\mathrm{mg} / \mathrm{kg})$} & $<100$ & 0 \\
\hline & $100-1000$ & -1 \\
\hline & $>1000$ & -4 \\
\hline \multirow{3}{*}{$\mathrm{SO}_{4}^{2-}(\mathrm{mg} / \mathrm{kg})$} & $<200$ & 0 \\
\hline & $200-300$ & -1 \\
\hline & $>300$ & -2 \\
\hline \multirow{3}{*}{$S^{2-}(\mathrm{mg} / \mathrm{kg})$} & Absent & 0 \\
\hline & $<0.5$ & -2 \\
\hline & $>0.5$ & -4 \\
\hline
\end{tabular}

of chloride, sulfate, and sulfide remained the same for this proposition because more analyses must be conducted to establish the corrosivity level taking into account each parameter. In this method, the SRB analysis was not suggested due to the short time window to conduct the measurements after the soil collection, which would hinder or compromise the whole analysis. Furthermore, the redox potential is already a strategy to observe if the soil has or not favorable conditions to anaerobic microbiological activity ${ }^{11,45}$.

The sum of the indexes indicates the soil aggressiveness, according to Table 9, that maintains the same criterion used in the Steinrath index ${ }^{19}$.

Figure 8 shows the classification of each soil studied using the index proposed in this work. It is possible to observe that the classification has changed from the Steinrath index in Figure 4d, in which only soil 2 and 4 presented high corrosivity while soil 3 and 6 presented none. Also, the results found were similar to the electrochemical analyses.

\subsection{Analyses of soil corrosivity based on electrochemical parameters}

As observed in the previous sections (Table 4 and Table 5), the corrosion resistance decreases with an increase in the presence of salts, being the soils with higher amounts of chloride and sulfate, the ones considered more aggressive ${ }^{2,25,27}$.

Soils 2 and 5 presented a higher chloride concentration among all soils (Table 4) however, soil 5 was more aggressive than soil 2 presenting higher current densities. Then, it is
Table 9. Criteria for soil aggressiveness.

\begin{tabular}{cc}
\hline Soil classification & Total aggressiveness index \\
\hline Non-aggressive & 0 \\
\hline Slightly aggressive & $-1--8$ \\
\hline Moderately aggressive & $-8--10$ \\
\hline Highly aggressive & $<-10$ \\
\hline
\end{tabular}

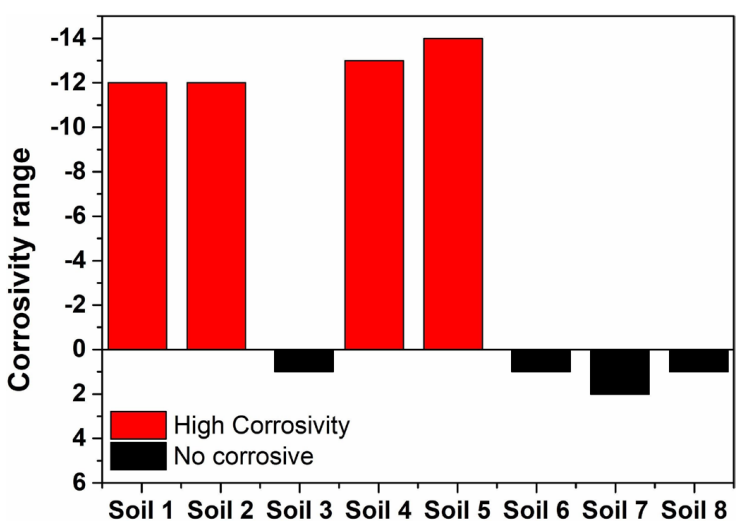

Figure 8. Corrosivity classification of soils in accordance with its physicochemical parameters by suggested index.

possible to infer that higher corrosion rates do not come from a single parameter but from a combination of them since soil 5 also presented a high amount of sulfate in its composition. The combination of high chloride and high sulfate might have led to its higher aggressiveness once that these ions attack the steel surface, intensifying the anodic dissolution ${ }^{52,53}$. The reactions that govern the anodic dissolution in the presence of these ions are:

$$
\begin{aligned}
& \mathrm{Fe}+2 \mathrm{Cl}^{-} \rightarrow \mathrm{FeCl}_{2}+2 e^{-} \\
& 4 \mathrm{FeCl}_{2}+8 \mathrm{OH}^{-}+\mathrm{O}_{2} \rightarrow 4 \mathrm{FeOOH}+8 \mathrm{Cl}^{-}+2 \mathrm{H}_{2} \mathrm{O} \\
& \mathrm{Fe}+\mathrm{SO}_{4}^{2-} \rightarrow \mathrm{FeSO}_{4}+2 e^{-} \\
& 4 \mathrm{FeSO}_{4}+8 \mathrm{OH}^{-}+\mathrm{O}_{2} \rightarrow 4 \mathrm{FeOOH}+4 \mathrm{SO}_{4}^{2-}+2 \mathrm{H}_{2} \mathrm{O}
\end{aligned}
$$

The reactions (1) and (3) correspond to the dissolution of $\mathrm{Fe} . \mathrm{FeCl}_{2}$ and $\mathrm{FeSO}_{4}$ are unstable products that are oxidized according to reactions (2) and (4), releasing chloride and sulfate ions again in the medium, restarting a new cycle ${ }^{53}$.

In the presence of chloride and sulfate, uniform corrosion occurs rapidly, creating a corrosion product layer consisting of an inner layer enriched with $\mathrm{S}^{-}$and an outer layer enriched with $\mathrm{Cl}^{-}$. The $\mathrm{Cl}^{-}$induces a localized anodic dissolution (pitting), and later the cyclic regeneration of the sulfuric acid dominates the initiation and fast growth of micro-cracks on the bottom of the pits ${ }^{54}$. Thus, the combined action of both ions is extremely aggressive for the buried structures.

These results support the fact that the soil corrosivity analyses should not be conducted by a single parameter and that even the most complete indexes such as AWWA should consider the presence of ions such as chloride and sulfate. This confirms the necessity of bringing a new and more complete criterion for the correct classification of 
soil aggressiveness, such as the one proposed in this study according to Table 8 and Table 9.

\subsection{Effect of $\mathrm{pH}$ and chloride concentration in modified soils on the electrochemical results}

The presence of chloride and $\mathrm{pH}$ are the main factors that affect soil corrosivity. Aiming to comprehend the influence of these factors, there were developed 3 modified soils (Table 2), adding chloride and cement using soil 8 as reference. The alkaline environment was obtained after the cement hydration $^{55}$. The addition of cement increased the $\mathrm{pH}$ to 12.8 , which is in agreement with other findings in the literature ${ }^{27}$.

The difference observed between the electrochemical results, corrosion potential, and current density (Figure 6) when comparing soils with alkaline and neutral $\mathrm{pH}$ is due to the formation of a stable corrosion product because of the high $\mathrm{pH}^{2}$. According to the Pourbaix diagram for iron, under alkaline environments, the value found for Ecorr is within the thermodynamic stability region of $\mathrm{Fe}_{3} \mathrm{O}_{4}$, a passive iron oxide. Consequently, the passive film on the steel surface increases the corrosion resistance ${ }^{2,56,57}$.

With the addition of chloride (Figure 6), the pitting potential decreased dramatically, indicating higher susceptibility for localized corrosion caused by the presence of these ions. The chloride ions are extremely aggressive, having a strong penetrability in the passive film, reaching the steel/oxide interface easily. Then, the passive film, even in alkaline soil, can be damaged by presence of chloride, decreasing its barrier capacity and the pitting potential ${ }^{2,3,25,26}$.

\subsection{Analyses of the proposed synthetic solutions}

Considering the analyses of the soil aqueous extracts, the presence of contaminants led to different current densities for the steel. When aiming to simulate distinct characteristics of soils in the lab through synthetic solutions, it is possible to observe that NS4 standard solutions do not represent the wide range found for soils in general, bringing the necessity of the proposal of new synthetic solutions, as shown in Table 3. The addition of chloride, under the concentrations used in this work, increased significantly the corrosivity of the synthetic solutions in relation to NS4. This is clearly seen by the increase in the current density of SS-Cl (Table 7).

On the other hand, the polarization curve for solution SS-SBR indicated lower current densities than NS4 (Table 7). This behavior is addressed to the possible formation of a protective film on the steel surface as a result of the steel corrosion in the medium with the presence of thiosulfate. The $\mathrm{H}_{2} \mathrm{~S}$ is formed by the thiosulfate reduction during the corrosive process $^{58}$, which in its turn may react with the steel surface forming a black film of iron sulfide (FeS). This film is composed mainly of mackinawite $\left(\mathrm{Fe}_{(1+\mathrm{x})} \mathrm{S}\right)$, a metastable phase $^{58-61}$. The fast formation of this film in solutions with thiosulfate is due to a local increase in $\mathrm{pH}$, the presence of elemental sulfur, and a higher concentration of $\mathrm{Fe}^{2+}$ during the corrosion processes. Sridhar ${ }^{60}$ reported that, under $\mathrm{H}_{2} \mathrm{~S}$ environments, the polarization curves indicate an active behavior however, the corrosion products formed may interfere with slight protection. The stability of iron sulfide films varies with the concentration of $\mathrm{H}_{2} \mathrm{~S}$ and the solution $\mathrm{pH}^{61}$.
Hydrogen sulfide is formed during the steel corrosion in solutions with thiosulfate according to the following reactions $^{58}$ :

$$
\begin{array}{ll}
\mathrm{S}_{2} \mathrm{O}^{2-}+6 \mathrm{H}^{+}+4 e^{-}=2 \mathrm{~S}^{0}+3 \mathrm{H}_{2} \mathrm{O} & E_{0}=0.465 V_{S H E} \\
2 \mathrm{~S}^{0}+4 \mathrm{H}^{+}+4 e^{-}=2 \mathrm{H}_{2} \mathrm{~S} & E_{0}=0.142 V_{S H E}
\end{array}
$$

The stability diagram for various sulfur compounds confirms that the corrosion potential of steel lies inside the stability region of $\mathrm{H}_{2} \mathrm{~S}$ according to the $\mathrm{E}$ vs. $\mathrm{pH}$ diagram for thiosulfate and $\mathrm{H}_{2} \mathrm{~S}$ thermodynamic equilibrium in aqueous solutions, as shown in Figure 9.

When dissolved in an aqueous solution and in contact with steel, the thiosulfate ion reacts to form small quantities of $\mathrm{H}_{2} \mathrm{~S}$ close to the steel surface. Similarly, the SRB metabolism generates $\mathrm{H}_{2} \mathrm{~S}$ in the medium therefore it is possible to correlate and simulate the bacterial activity using thiosulfate [24]. The $\mathrm{SRB}$ reduces $\mathrm{SO}_{4}^{2-}$ to $\mathrm{S}^{2-}$ that, when combined with $\mathrm{Fe}^{2+}$ released by the steel anodic dissolution, forms FeS, according to reactions (7) and (12) $)^{28,30,63}$.

$$
\begin{aligned}
& 4 \mathrm{Fe} \rightarrow 4 \mathrm{Fe}^{2+}+8 e \\
& 8 \mathrm{H}_{2} \mathrm{O} \rightarrow 8 \mathrm{H}^{+}+8 \mathrm{OH}^{2-} \\
& 8 \mathrm{H}^{+}+8 e \rightarrow 8[\mathrm{H}] \\
& \mathrm{SO}_{4}^{2-}+8[\mathrm{H}] \rightarrow \mathrm{S}^{2-}+4 \mathrm{H}_{2} \mathrm{O} \\
& 4 \mathrm{Fe}^{2+}+\mathrm{S}^{2-} \rightarrow \mathrm{FeS}
\end{aligned}
$$

$4 \mathrm{Fe}+\mathrm{SO}_{4}^{2-}+4 \mathrm{H}_{2} \mathrm{O} \stackrel{\mathrm{SRB}}{\rightarrow} 3 \mathrm{Fe}(\mathrm{OH})_{2}+\mathrm{FeS}+2 \mathrm{OH}^{-}$

Regardless of the formation of FeS on the steel surface, the presence of thiosulfate also induces the appearance of pitting corrosion, increasing the susceptibility of $\mathrm{SCC}^{64}$. This is another phenomenon observed in the corrosive processes caused by $\mathrm{SRB}^{30}$.

The SS-Cl was the most aggressive solution among all evaluated due to the presence of chloride. Several works in

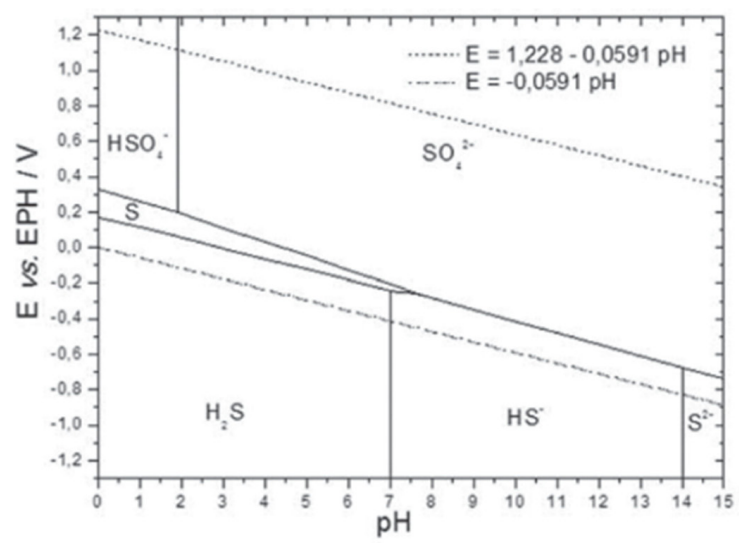

Figure 9. Diagram E vs. $\mathrm{pH}$ for thiosulphate and $\mathrm{H}_{2} \mathrm{~S}$ thermodynamic equilibrium in aqueous solutions ${ }^{62}$. 
the literature reported that an increase in corrosion rates is

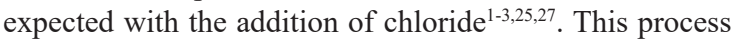
leads to forming a non protective layer of corrosion products that promote the diffusion of chloride ions, forming pitting corrosion $^{1-3,25}$.

As mentioned previously, the hydration of cement increases the $\mathrm{pH}^{55}$. According to the Pourbaix Diagram for the steel, under alkaline environments, the passive oxide $\mathrm{Fe}_{3} \mathrm{O}_{4}$ is formed thermodynamically, decreasing the current density. The polarization curves of SS-ALK and SS-SRBALK were similar (Figure 7), indicating that cement inhibits the increase of corrosivity caused by the reduction of sulfate. The literature indicates that soils treated with cement can resist corrosion caused by sulfate ions when $10 \%$ wt. of cement is adde ${ }^{55}$. However, in this work $5 \%$ wt. was sufficient to promote this inhibition.

Although alkalinity was reached in SS-Cl-ALK, seen by the decrease in the current density, the chloride ions presented high penetrability. Therefore, even with the formation of a passive film on the steel surface, the addition of chloride possibly was responsible for damages ${ }^{2,56}$ that led to an increase in the current density, verified by the results in Figure 7 .

As indicated in Table 4 and Table 6 , the synthetic solutions were more aggressive than the soils studied. This is due to the fact that the solutions simulate soils with different concentrations of ions such as chloride and thiosulfate. Then, the proposed solutions can be used for laboratory tests which aims to simulate soils with specific characteristics.

\section{Conclusions}

- The methods for classification of soils in which only one parameter is considered, such as resistivity and redox potential, may generate divergent results and compromise the evaluation of soil corrosivity leading to premature failures in the buried structures.

- The criteria that considered the higher number of physicochemical parameters were Steinrath and Steinrath modified. However, even with these indexes, the range considered as corrosive by the presence of sulfates proved to be inefficient, which became evident by the electrochemical analyses.

- $\quad$ The combined influence of chlorides and sulfates increasing the corrosivity of soils and synthetic solutions was observed through electrochemical tests due to the increase in the current density and reduction of the corrosion potential.

- A new index of soil corrosivity was proposed, aiming to cover the positive characteristics of each criterion studied in this work. The corrosivity analyses using this new index showed a significant change in relation to the Steinrath index, with more reliability being in agreement with the electrochemical results.

- The solution NS4 proved to be inefficient to simulate a wide range of soils, bringing the necessity of the development of new solutions that would cover a wider range of physicochemical parameters.

- The solutions alkalinization using cement was sufficient to reduce the current densities significantly on the tests with the steel carbon. Also, the addition of chloride and thiosulfate were representative of simulating seashore environments and with the presence of SRB.

\section{Acknowledgments}

The present work was carried out with the support of the Research Support Foundation of Minas Gerais - FAPEMIG. The authors would like to thank the Federal University of São João del-Rei for the use of their facilities.

\section{References}

1. Wu W, Liu Z, Li X, Du C. Electrochemical characteristic and stress corrosion behavior of API X70 high-strength pipeline steel under a simulated disbonded coating in an artificial seawater environment. J Electroanal Chem (Lausanne Switz). 2019;845:92-105.

2. Wang Y, Cheng G, Wu W, Qiao Q, Li Y, Li X. Effect of pH and chloride on the micro-mechanism of pitting corrosion for high strength pipeline steel in aerated $\mathrm{NaCl}$ solutions. Appl Surf Sci. 2015;349:746-56.

3. Wu W, Hao W, Liu Z, Li X, Du C. Comparative study of the stress corrosion behavior of a multiuse bainite steel in the simulated tropical marine atmosphere and seawater environments. Constr Build Mater. 2020;239:117903.

4. Daku SS, Diyelmak VB, Otitolaiye OA, Abalaka IE. Evaluation of soil corrosivity using electrical resistivity method: a case study of part of the university of jos permanent site. Sci Res J. 2019; VII:66-76.

5. Sherar BWA, Keech PG, Shoesmith DW. The effect of sulfide on the aerobic corrosion of carbon steel in near-neutral $\mathrm{pH}$ saline solutions. Corros Sci. 2013;66:256-62.

6. Akkouche R, Rémazeilles C, Jeannin M, Barbalat M, Sabot R, Refait P. Influence of soil moisture on the corrosion processes of carbon steel in artificial soil: active area and differential aeration cells. Electrochim Acta. 2016;213:698-708.

7. Xu J, Bai Y, Wu T, Yan M, Yu C, Sun C. Effect of elastic stress and alternating current on corrosion of X80 pipeline steel in simulated soil solution. Eng Fail Anal. 2019;100:192-205.

8. Bueno AHS, Moreira ED, Siqueira P, Gomes JACP. Effect of cathodic potential on hydrogen permeation of API grade steels in modified NS4 solution. Mater Sci Eng A. 2014;597:117-21.

9. Contreras A, Hernández SL, Orozco-Cruz R, Galvan-Martínez $R$. Mechanical and environmental effects on stress corrosion cracking of low carbon pipeline steel in a soil solution. Mater Des. 2012;35:281-9.

10. Azoor RM, Deo RN, Birbilis N, Kodikara J. On the optimum soil moisture for underground corrosion in different soil types. Corros Sci. 2019;159:108116.

11. Ismail AIM, El-Shamy AM. Engineering behaviour of soil materials on the corrosion of mild steel. Appl Clay Sci. 2009;42:356-62.

12. Petersen RB, Melchers RE. Bi-modal trending for corrosion loss of steels buried in soils. Corros Sci. 2018;137:194-203.

13. Cole IS, Marney D. The science of pipe corrosion: 13 of the literature on the corrosion of ferrous metals in soils. Corros Sci. 2012;56:5-16.

14. Doyle G, Seica MV, Grabinsky MWF. The role of soil in the external corrosion of cast iron water mains in Toronto, Canada. Can Geotech J. 2003;40:225-36.

15. De Arriba-Rodriguez L, Villanueva-Balsera J, Ortega-Fernandez F, Rodriguez-Perez F. Methods to evaluate corrosion in buried steel structures: a review. Metals (Basel). 2018;8(5):334.

16. Starkey RL, Wight KM. Anaerobic corrosion of iron in soil. Nova York: John Wiley and Sons; 1971.

17. Robison WC. Testing soil for corrosiveness environmental effects. Mater Perform. 1993;32(4):56-8. 
18. AWWA: American Water Works Association. ANSI/AWWA C105/A21.5-99: American National Standard for Polyethylene Encasement for Ductile-Iron Pipe Systems. USA: AWWA; 1999.

19. Trabanelli G, Zucchi F, Arpaia M. Methods of determination of soil corrosiveness with respect to metallic structures. Chinica Pura ed Appl. 1972;3:43-59.

20. Magalhães FCM, Baptista W, Penna MO, Silva ED, Oliveira HB, Costa JCM. Critérios para a avaliação da corrosividade

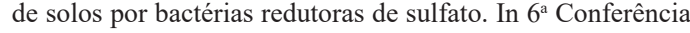
sobre Tecnologia de Equipamentos; 2002 Ago 19-21; Salvador. 2002.

21. Sani, F. M., Afshar, A. \& Mohammadi, M. Evaluation of the simultaneous effects of sulfate reducing bacteria, soil type and moisture content on corrosion behavior of buried carbon steel API 5L X65. Int J Electrochem Sci. 2016;11(5):3887-3907.

22. Galai M, Choucri J, Hassani Y, Benqlilou H, Mansouri I, Ouaki B, Ebn Touhami M, Monticelli C, Zucchi F. Moisture content and chloride ion effect on the corrosion behavior of fitting brass (gate valves) used as a connection of PVC's conduits in aggressive sandy soil. Chem Data Collect. 2019;19:100171.

23. Ezuber HM, Alshater A, Hossain SMZ, El-Basir A. Impact of soil characteristics and moisture content on the corrosion of underground steel pipelines. Arab J Sci Eng. 2021;46:6177-88 http://dx.doi.org/10.1007/s13369-020-04887-8.

24. Wang MM, Tasan CC, Ponge D, Dippel AC, Raabe D. Nanolaminate transformation-induced plasticity-twinning-induced plasticity steel with dynamic strain partitioning and enhanced damage resistance. Acta Mater. 2015;85:216-28.

25. You Z, Lai Y, Zeng H, Yang Y. Influence of water and sodium chloride content on corrosion behavior of cast iron in silty clay. Constr Build Mater. 2020;238:117762.

26. Am E, Mf S, Him M, Melegy A. Chloride ions penetration and their role in sediments corrosion of buried steel structures in closed basin. Chem Sci J. 2016;7:1-7.

27. Katiyar PK, Randhawa NS. Corrosion behavior of WC-Co tool bits in simulated (concrete, soil, and mine) solutions with and without chloride additions. Int J Refract Met Hard Mater. 2019;85:105062.

28. Xie F, Li X, Wang D, Wu M, Sun D. Synergistic effect of sulphate-reducing bacteria and external tensile stress on the corrosion behaviour of X80 pipeline steel in neutral soil environment. Eng Fail Anal. 2018;91:382-96.

29. Liu H, Cheng YF. Microbial corrosion of initial perforation on abandoned pipelines in wet soil containing sulfate-reducing bacteria. Colloids Surf B Biointerfaces. 2020;190:110899.

30. Wu T, Yan M, Yu L, Zhao H, Sun C, Yin F, Ke W. Stress corrosion of pipeline steel under disbonded coating in a SRB-containing environment. Corros Sci. 2019;157:518-30.

31. Luo J, Luo S, Li L, Zhang L, Wu G, Zhu L. Stress corrosion cracking behavior of X90 pipeline steel and its weld joint at different applied potentials in near-neutral solutions. Nat Gas Ind B. 2019;6:138-44.

32. Contreras A, Hernández SL, Orozco-cruz R, Galvan-martínez R. Mechanical and environmental effects on stress corrosion cracking of low carbon pipeline steel in a soil solution. Mater Des. 2012;35:281-9.

33. Parkins RN, Blanchard WK, Delanty BS. Transgranular stress corrosion cracking of high-pressure pipelines in contact with solutions of near neutral pH. Corrosion. 1994;50:394-408.

34. ABNT: Associação Brasileira de Normas Técnicas. ABNT NBR7117. Medição da resistividade e determinação da estratificação do solo. Rio de Janeiro: ABNT; 2012.

35. British Standard. BS 1377. Methods of test for Soils for Civil Engineering purposespart 9. UK: British Standard; 1990.

36. Postgate JR. The sulfhate - reducing bacteria. Cambridge: Cambridge University Press; 1984.
37. Harrison AP Jr. Microbial sucession and mineral leaching in a artificial coal spoil. Appl Enviroumental Microbiol. 1982;36(6):861-9.

38. Serra ET. Corrosão e proteção anticorrosiva dos metais no solo. Interciencia. 2014

39. Aballe A, Bethencourt M, Botana FJ, Cano MJ, Marcos M. Localized alkaline corrosion of alloy AA5083 in neutral 3.5\% $\mathrm{NaCl}$ solution. Corros Sci. 2001:43(9):1657-74. http://dx.doi. org/10.1016/S0010-938X(00)00166-9.

40. Tristijanto H, Ilman MN, Tri Iswanto P. Corrosion inhibition of welded of $\mathrm{X}-52$ steel pipelines by sodium molybdate in 3.5\% NaCl solution. Egypt J Pet. 2020;29(2):155-62. http:// dx.doi.org/10.1016/j.ejpe.2020.02.001.

41. Bueno AHS, Ventin FF, Castro BB, Ponciano JAC. Avaliação da corrosividade de solos. in $7^{\circ}$ COETQ (2003).

42. Tiller AK,. A review of the European Research effort on microbia corrosion between 1950 and 1984. In: Biologically Induced Corrosion. Houston, Texas: Nace S.C. Dexter ed, 1985.

43. Pourbaix M. Lições de corrosão eletroquímica. Belgium: Cebelcor; 1987.

44. Ponciano JACG, Bueno AHS. Avaliação preliminar de processo corrosivo externo e de suas medidas de controle em minerodudo enterrado. Rio de Janeiro: COPPE/UFRJ; 2003.

45. Ganiyu SA, Olurin OT, Ajibodu KA, Badmus BS, Ajayi AO. Assessment of the degree of external corrosion of buried water pipelines and source identification of heavy metals due to surrounding soil conditions in humid environment. Environ Earth Sci. 2018;77:1-18.

46. Alamilla JL, Espinosa-Medina MA, Sosa E. Modelling steel corrosion damage in soil environment. Corros Sci. 2009;51:262838.

47. Bradford SA. Corrosion controls. New York: Van Nostrand Reinhold; 1993.

48. Little B, Wagner P, Mansfeld F. An overview of microbiologically influenced corrosion. Electrochim Acta. 1992;37:2185-94.

49. Telegdi J, Shaban A, Trif L. Microbiologically influenced corrosion (MIC). In: El-Sherik AM, editor. Trends in oil and gas corrosion research and technologies: production and transmission. Sawston, Reino Unido: Woodhead Publishing; 2017. p. 191-214. http://dx.doi.org/10.1016/B978-0-08-1011058.00008-5.

50. Santos BAF, Serenario MED, Souza RC, Oliveira JR, Vaz GL, Gomes JACP. The electrolyte renewal effect on the corrosion mechanisms of API X65 carbon steel under sweet and sour environments. J Petrol Sci Eng. 2021;199:108347.

51. Serra ET. Corrosão pelo solo: agentes, avaliação e soluções. Eletr Mod. 1982;11:28-36.

52. Mahidashti Z, Rezaei M, Asfia MP. Internal under-deposit corrosion of X60 pipeline steel upon installation in a chloridecontaining soil environment. Colloids Surf A Physicochem Eng Asp. 2020;602:125120.

53. Zhang X, Xiao K, Dong C, Wu J, Li X, Huang Y. In situ Raman spectroscopy study of corrosion products on the surface of carbon steel in solution containing Cl- and SO42-. Eng Fail Anal. 2011;18(8):1981-9.

54. Wu W, Liu Z, Li X, Du C, Cui Z. Influence of different heataffected zone microstructures on the stress corrosion behavior and mechanism of high-strength low-alloy steel in a sulfurated marine atmosphere. Mater Sci Eng A. 2019;759:124-41.

55. Xiaoyuan W, Pengju H, Xiaohong B, Xiangyu L. Influences of slag on properties of lightweight cement-treated soils subjected to sulfate corrosion. Constr Build Mater. 2019;205:511-8.

56. Maslehuddin M, Al-Zahrani MM, Ibrahim M, Al-Mehthel $\mathrm{MH}, \mathrm{Al}$-Idi SH. Effect of chloride concentration in soil on reinforcement corrosion. Constr Build Mater. 2007;21:1825-32.

57. Meek AH, Beckett CTS, Carsana M, Ciancio D. Corrosion protection of steel embedded in cement-stabilised rammed earth. Constr Build Mater. 2018;187:942-53. 
58. Kappes M, Frankel GS, Sridhar N, Carranza RM. Reaction paths of thiosulfate during corrosion of carbon steel in acidified brines. J Electrochem Soc. 2012;159:C195-204.

59. Cabrini M, Lorenzi S, Pastore T. Effects of thiosulphates and sulphite ions on steel corrosion. Corros Sci. 2018;135:158-66.

60. Sridhar N. Effects of water and gas compositions on the internal corrosion of gas pipelines-modeling and experimental studies. Corrosion. 2001;57:221-34.

61. Huang F, Cheng P, Zhao XY, Liu J, Hu Q, Frank Cheng Y. Effect of sulfide films formed on X65 steel surface on hydrogen permeation in $\mathrm{H} 2 \mathrm{~S}$ environments. Int J Hydrogen Energy. 2017;42(7):4561-70.
62. Oliveira M, Lima A, Figueredo R, Acciari H, Codaro E. Um estudo termodinâmico da corrosão dos aços carbono pelo sulfeto de hidrogênio - explorando conceitos de equilíbrio químico. Quim Nova. 2018;41:594-9.

63. Zhu SD, Wei JF, Cai R, Bai ZQ, Zhou GS. Corrosion failure analysis of high strength grade super $13 \mathrm{Cr}-110$ tubing string. Eng Fail Anal. 2011;18:2222-31.

64. Tian H, Wang X, Cui Z, Lu Q, Wang L, Lei L, Li Y, Zhang D. Electrochemical corrosion, hydrogen permeation and stress corrosion cracking behavior of E690 steel in thiosulfate-containing artificial seawater. Corros Sci. 2018;144:145-62. 